\title{
PRICING TO MARKET, STAGGERED CONTRACTS, AND REAL EXCHANGE RATE PERSISTENCE
}

\author{
Paul R. Bergin \\ Robert C. Feenstra
}

Working Paper 7026

http://www.nber.org/papers/w7026

\author{
NATIONAL BUREAU OF ECONOMIC RESEARCH \\ 1050 Massachusetts Avenue \\ Cambridge, MA 02138 \\ March 1999
}

\begin{abstract}
Special thanks go to Charles Engel and Patrick Asea for detailed comments. We also thank the participants in the NBER summer institute on International Finance and Money and seminar participants at the University of Washington. The views expressed in this paper are those of the authors and do not reflect those of the National Bureau of Economic Research.

(C) 1999 by Paul R. Bergin and Robert C. Feenstra. All rights reserved. Short sections of text, not to exceed two paragraphs, may be quoted without explicit permission provided that full credit, including $(\mathbb{C}$ notice, is given to the source.
\end{abstract}


Pricing to Market, Staggered Contracts, and Real Exchange Rate Persistence

Paul R. Bergin and Robert C. Feenstra

NBER Working Paper No. 7026

March 1999

JEL No. F41, F31

\section{ABSTRACT}

This paper offers an explanation for the persistence observed in real exchange rate movements. The model combines pricing to market behavior with sticky prices generated by staggered contracts. A translog preference structure is used to enhance both features. The paper finds that openness limits the degree of endogenous persistence. Nevertheless, the model under reasonable parameter values can replicate the serial correlation of real exchange rate data. Further, significant exchange rate volatility can be generated, and this is amplified by the presence of endogenous persistence.

Paul R. Bergin

Department of Economics

University of California, Davis

Davis, CA 95616

pbergin@ucdavis.edu
Robert C. Feenstra

Department of Economics

University of California, Davis

Davis, CA 95616

and NBER

rcfeenstra@ucdavis.edu 


\section{Introduction}

A prominent question in international macroeconomics is why real exchange rates exhibit persistent deviations from purchasing power parity. Table 1 reiterates the basic findings of the preceding literature, using quarterly data for 1973-1997. ${ }^{1}$ Averaging over countries, the onequarter autocorrelation is about 0.8 , and that over four quarters is $0.27 .^{2}$ A related time-series literature concludes that the real exchange rate may be even more persistent. ${ }^{3}$ In addition, the table shows the real exchange rate is quite volatile, with a standard deviation between four to five times that of output on average.

Sticky prices are one explanation commonly offered for these real exchange rate movements. Monetary shocks could induce an immediate change in the nominal exchange rate, and this would translate into a change in the real exchange rate if national price levels remain fixed. Intertemporal models presenting this general view include Svensson and van Wijnbergen (1989), Obstfeld and Rogoff (1995), and Kollmann (1996).

A second explanation focuses on pricing-to-market, in which a firm intentionally sets different prices for its good across segmented national markets. ${ }^{4}$ This explanation is consistent with empirical work by Engel (1993), Knetter (1993) and others, which have documented

1 The table closely resembles standard findings in the real business cycle literature: see Backus, Kehoe, and Kydland (1992), Chari, Kehoe and McGrattan (1998a), and Chang and Devereux (1998).

2 All data are logged and Hodrick-Prescott filtered quarterly series. The real exchange rate is computed as the CPI-adjusted bilateral exchange rate with the U.S. dollar. If we do not Hodrick-Prescott filter the real exchange rate data, the average serial correlation naturally is much higher: 0.94 for one quarter and 0.71 for four quarters.

3 See Froot and Rogoff (1995) for a summary of the time series literature. Several studies suggest real exchange rate deviations have a half-life of about four to five years. Some studies, such as Engel (1999), cast doubt on whether the real exchange rate is even mean reverting.

4 A related explanation for deviations from the law of one price, suggested in Devereux (1997), is that prices are sticky in the local currency of the buyer. 
significant deviations from the law of one price. First developed in a partial equilibrium setting (see Dornbusch (1987), Krugman (1987), Knetter (1989) and Marston (1990)), pricing-tomarket has been adapted to general equilibrium settings by Betts and Devereux $(1996,1998)$, Chang and Devereux (1998), Chari, Kehoe and McGrattan (1998a), and Devereux and Engel (1998).

Nevertheless, the persistence of real exchange rate movements has posed a significant challenge to theoretical models. Chang and Devereux (1998) find that without price stickiness, a model of pricing-to-market cannot generate adequate persistence. Chari, et al. (1998a) find that sticky prices can help replicate persistence in the data, but only if one is willing to accept long-lived price contracts, which set prices for at least three years. It is generally thought that price-setting contracts are shorter than this in practice, and that it would be desirable to have a model in which prices and real exchange rate deviations last longer than the rigidity imposed exogenously by the contract. This is called endogenous persistence. In principle, overlapping contracts of the type described by Taylor (1980) and Blanchard (1983) should generate such endogenous persistence. However, Chari, et al. (1998a) find this is not the case in a general equilibrium setting.

The present paper will consider an extension of the two-country model of Obstfeld and Rogoff (1995), augmented to allow for pricing-to-market and staggered price contracts. The model incorporates several features that Bergin and Feenstra (1998) found useful in generating endogenous persistence in a closed economy context. These features include a translog demand structure and a particular production structure proposed by Basu (1995). Kimball (1995) discusses the importance of a demand with a nonconstant elasticity for generating significant real effects of monetary shocks. The translog specification we develop here is one example which has the virtue of analytical tractability. It has been argued in Bergin and Feenstra (1998) that a demand structure with a nonconstant elasticity is necessary in a general equilibrium set- 
ting to generate the interactions of staggered price setters envisioned by Taylor and Blanchard. The present paper demonstrates that such a demand structure is likewise necessary to generate genuine pricing-to-market.

The paper finds that a greater degree of openness in an economy, by its nature, limits the degree of endogenous persistence. The presence of foreign goods causes the domestic price index to adjust more quickly to a monetary shock. Nevertheless, for reasonable parameter values the model can generate a significant amount of endogenous persistence in the real exchange rate. The model produces more persistence than past studies, and for reasonable parameter values, it is able to replicate the serial correlations in the data used as a benchmark in this literature. Translog preferences and the production structure play key roles in this result. It is also found that the model can generate exchange rate overshooting and significant exchange rate volatility. Finally, there appears to be interactions between volatility and persistence. For example, greater persistence tends to amplify exchange rate overshooting and thereby the degree of volatility.

The next section of the paper discusses the model framework. Results are presented in section three, first discussing persistence of the real exchange rate and then discussing volatility. We obtain analytical results for a particular set of preference parameters, and simulation results for other parameter values. Section 4 concludes.

\section{The Model}

\subsection{Households}

Consider a model of two countries, hereafter referred to as home and foreign. Variables in the foreign country will be denoted by an asterisk. In addition, when necessary for clarity a subscript $h$ will denote a variable originating in the home country; a subscript $f$ will denote a 
variable in originating in the foreign country.

The households in the home country are endowed each period with one unit of time, which they divide between leisure and work. They consume a continuum of differentiated goods. Home households can hold three types of nominal assets: non-interest bearing home money $(M)$, interest bearing one-period nominal debt denominated in the currency of the home country $\left(B_{h}\right)$, or debt denominated in the currency of the foreign country $\left(B_{f}\right)$. Money holding is motivated through the utility function. Household income is derived from selling labor $(L)$ to firms at wage rate $(W)$, profits from firms $(\Pi)$, from the interest received on bonds (at rates $R$ and $R^{*}$ ), and lump-sum government transfers $(T)$. Let $U$ represent the sub-utility obtained from consumption of the differentiated products, and let $P$ be the home unit price index consistent with this consumption composite. Let $S$ denote the nominal exchange rate, defined as the domestic currency price of one unit of foreign exchange. International linkages in the model work through household trade in the goods and bond markets. There is no trade in firm equities, and no international mobility in labor. As in Obstfeld and Rogoff (1995), there is no capital accumulation in the model. ${ }^{5}$

Households in the home country solve the problem: ${ }^{6}$

$\max E_{t} \sum_{t=0}^{\infty} \beta^{t} \begin{cases}{\left[\frac{1}{\left(1-\sigma_{1}\right)} U_{t}^{1-\sigma_{1}}+\frac{1}{\left(1-\sigma_{2}\right)}\left(\frac{M_{t}}{P_{t}}\right)^{1-\sigma_{2}}-\frac{L_{t}^{1+\sigma_{3}}}{1+\sigma_{3}}\right]} & \text { for } \sigma_{1} \neq 1, \sigma_{2} \neq 1 \\ {\left[\log U_{t}+\log \left(\frac{M_{t}}{P_{t}}\right)-\frac{L_{t}^{1+\sigma_{3}}}{1+\sigma_{3}}\right]} & \text { for } \sigma_{1}=1, \sigma_{2}=1\end{cases}$

5 In Bergin and Feenstra (1998), it is demonstrated that capital accumulation has only very small effects on persistence generated by the mechanisms of the type used in this paper. In fact for reasonable investment adjustment costs, capital accumulation can even somewhat increase the persistence of real effects following a nominal shock. We do not discuss this issue in detail here, because the focus of the present paper is exchange rate determination rather than business cycles.

6 Chari, et. al. (1998) demonstrate that preferences separable in leisure are important for generating real exchange rate volatility. 
where the budget constraint is:

$P_{t} U_{t}+B_{h t}+S_{t} B_{f t}+M_{t}=W_{t} L_{t}+\left(1+R_{t-1}\right) B_{h t-1}+S_{t}\left(1+R_{t-1}^{*}\right) B_{f t-1}+M_{t-1}+\Pi_{t}+T_{t}$

The analytical results in this paper will focus mainly on the case of complete financial markets, although the alternative case of incomplete markets will be considered in model simulations. The benchmark case assumes a complete set of contingent assets that can be traded to perfectly share all risks between home and foreign households. This implies an optimization problem that maximizes the sum of (1) and its foreign counterpart, subject to the budget constraint (2) combined with its foreign counterpart, once converted to domestic currency terms using the nominal exchange rate $S_{t}$.

The first-order conditions for this problem include the home intertemporal Euler equation:

$$
\beta\left(1+R_{t}\right) E_{t}\left[\frac{P_{t+1} U_{t+1}^{\sigma_{1}}}{P_{t} U_{t}^{\sigma_{1}}}\right]=1
$$

money demand:

$$
\left(\frac{M_{t}}{P_{t}}\right)^{-\sigma_{2}}=\frac{U_{t}^{-\sigma_{1}} R_{t}}{\left(1+R_{t}\right)}
$$

labor supply:

$$
L_{t}^{\sigma_{3}}=\frac{W_{t}}{P_{t} U_{t}^{\sigma_{1}}}
$$

and a set of foreign counterparts. The problem also produces the following risk-sharing relation between home and foreign marginal utilities of consumption:

$$
\frac{U_{t}^{*^{\prime}}}{U_{t}^{\prime}}=\frac{S_{t} P_{t}^{*}}{P_{t}}
$$


Note that the intertemporal condition (3) along with its foreign counterpart and the risk-sharing relation jointly imply the following uncovered interest parity condition:

$$
S_{t}=\left(\frac{1+R_{t}^{*}}{1+R_{t}}\right)\left(\frac{E_{t}\left[S_{t+1} /\left(P_{t+1} U_{t+1}^{\sigma_{1}}\right)\right]}{E_{t}\left[1 /\left(P_{t+1} U_{t+1}^{\sigma_{1}}\right)\right]}\right)
$$

For the alternative case of incomplete markets, we assume the only assets traded are the noncontingent nominal bonds. This implies two distinct optimization problems, one regarding home preferences (1) subject to the home budget constraint (2), and the other regarding foreign counterparts. Consequently, the risk sharing condition (6) does not hold. This is replaced by the following balance of payments constraint

$S_{t} P_{h t}^{*}\left(X_{h t}^{*}+Z_{h t}^{*}\right)-P_{f t}\left(X_{f t}+Z_{f t}\right)-S_{t} B_{f t}+B_{h t}^{*}+S_{t}\left(1+R_{t-1}^{*}\right) B_{f t-1}-\left(1+R_{t-1}\right) B_{h t-1}^{*}=0$

implied by the home national budget constraint.

As in Bergin and Feenstra (1998), we will allow the sub-utility, $U$, in equation (1) to be defined by the dual expenditure function, which is assumed to have a translog form. ${ }^{7}$ This unit-expenditure function is defined by:

$$
\ln P_{t}=f\left(P_{1 t}, \ldots P_{N t}\right)=\sum_{i=1}^{N} \alpha_{i} \ln P_{i t}+\frac{1}{2} \sum_{i=1}^{N} \sum_{j=1}^{N} \gamma_{i j} \ln P_{i t} \ln P_{j t}
$$

where $P_{i}$ is the price of good $i$ and where $\gamma_{i j}=\gamma_{j i}$. In order for this function to be homogeneous of degree one, we need to impose the conditions:

$$
\sum_{i=1}^{N} \alpha_{i}=1 \text { and } \sum_{i=1}^{N} \gamma_{i j}=\sum_{j=1}^{N} \gamma_{i j}=0
$$

7 That is, given nominal expenditure $E_{t}$, the sub-utility from consumption of the differentiated products $1, \ldots, \mathrm{N}$ is $U_{t}=E_{t} / f\left(P_{1 t}, \ldots, P_{N t}\right)$. We do not use the notation $E_{t}$ for nominal expenditure in the text, but reserve this for the expectation operator. 
We can differentiate the unit-expenditure function to obtain the expenditure shares, $\psi_{i}$ :

$$
\psi_{i t}=\partial \ln f\left(P_{1 t}, \ldots, P_{N t}\right) / \partial \ln P_{i t}=\alpha_{i}+\sum_{j=1}^{N} \gamma_{i j} \ln P_{j t}
$$

The home-country demand for each good then may be written:

$$
X_{i t}=\psi_{i t} \frac{P_{t} U_{t}}{P_{i t}}
$$

The (positive) elasticity of demand for each differentiated product in the home country is computed as $\eta_{i t}=1-\frac{\partial \ln \psi_{i t}}{\partial \ln P_{i t}}=1-\frac{\gamma_{i i}}{\psi_{i t}}$, where $\gamma_{i i}<0$ is needed to ensure that demand is elastic.

While the equations above are the general case of the translog function, we can consider a special case where all goods enter symmetrically. In that case, the parameters become,

$$
\alpha_{i}=\frac{1}{N}, \gamma_{i i}=-\frac{\gamma}{N}, \text { and } \gamma_{i j}=\frac{\gamma}{N(N-1)} \text { for } j \neq i
$$

This choice of parameters satisfies the homogeneity conditions (10), and expressing the parameters as a ratio to $N$ ensures that the elasticity of demand remains bounded above even as $N$ becomes large, as we wish to consider in this paper. ${ }^{8}$

\subsection{Firm's Problem}

Firms sell their output to consumers, and also to other firms as intermediate inputs. Both the final goods and intermediate inputs will be traded internationally, though we shall introduce "home market bias" below. Each of the home differentiated varieties is produced with the Cobb-Douglas production function:

$$
Y_{i t}=A L_{t}^{\theta} Z_{t}^{1-\theta}
$$

8 Note that we do not allow $N$ to vary endogenously. Allowing $N$ to approach infinity is just a simplifying device. 
where $L_{t}$ refers to the demand for labor by home firms, with cost-share $\theta$, and where $Z_{t}$ is a composite intermediate input. (An analogous expression, with asterisks on all variables, holds for foreign production.) The composite intermediate input $Z_{t}$ is itself a translog aggregate of the home and foreign product varieties, using exactly the same functional form as for the translog expenditure function introduced above. Thus, the elasticity of demand for each final good will be identical to the elasticity of demand for each intermediate input, as given by $\eta_{i t}=1-\frac{\gamma_{i i}}{\psi_{i t}}$,with the share of each (final or intermediate) variety given by (11).

Denote the marginal cost of producing in the home country by $C_{t}$. Given the CobbDouglas production function in (14), the marginal costs are also a Cobb-Douglas function of the wages and aggregate price of the intermediates. These are denoted by $C_{t}=W_{t}^{\theta} P_{t}^{1-\theta}$, where $W_{t}$ is the nominal wage paid to labor, and $P_{t}$ is the aggregate price index. The same expression for marginal costs holds abroad, with an asterisk added to each variable. Because the production functions are Cobb-Douglas, they imply constant expenditure shares on the two inputs, labor and the composite intermediate good:

$$
\frac{P_{t} Z_{t}}{W_{t} L_{t}}=\frac{1-\theta}{\theta}
$$

Firms are assumed able to set a different price in the local currency in each country. Consider the problem for a firm located in the home country. Let $P_{i}$ be the price set by the firm for sale of the good in the home country, and $P_{i}^{*}$ for sale in the foreign country. Consider the case in which there are two groups of price setters in each country, each setting a price for two periods in staggered fashion. Firms are assumed to set their prices after observing the money shock for the first period of the contract, but before observing the shock for the second period. Denote the demand for product $i$ in the home country as $\left(X_{i t}+Z_{i t}\right)$ and the demand in the foreign country as $\left(X_{i t}^{*}+Z_{i t}^{*}\right)$. The profit-maximization problem for an individual home firm 
now is:

$$
\max E_{t} \sum_{\tau=t}^{t+1} \beta^{\tau-t}\left[\left(P_{i t}-C_{t}\right)\left(X_{i t}+Z_{i t}\right)+\left(S_{t} P_{i t}^{*}-C_{t}\right)\left(X_{i t}^{*}+Z_{i t}^{*}\right)\right]
$$

Using the elasticity of demand discussed above, the first order conditions may be written:

$$
\begin{aligned}
& E_{t} \sum_{\tau=t}^{t+1} \beta^{\tau-t}\left[\left(1-\frac{\psi_{i \tau}}{\gamma_{i i}}\right)\left(\frac{C_{\tau}}{P_{i t}}\right)-1\right]=0 \\
& E_{t} \sum_{\tau=t}^{t+1} \beta^{\tau-t}\left[\left(1-\frac{\psi_{i \tau}^{*}}{\gamma_{i i}}\right) \frac{C_{\tau}}{S_{\tau} P_{i \tau}^{*}}-1\right]=0
\end{aligned}
$$

The expenditure shares, $\psi_{i}$, can be substituted from (11), and then (17 and 18) can be solved for the optimal prices, in terms of marginal cost and the prices of competitors. This expression is nonlinear (involving $P_{i t}$ and $\ln P_{i t}$ ), so we will take an approximation to allow us to obtain a simple solution for the price. Take logs of both sides of (17 and 18), using $\ln \left(1-\frac{\psi_{i t}}{\gamma_{i i}}\right) \approx-\frac{\psi_{i t}}{\gamma_{i i}}$ (which is valid for $\psi_{i t}$ small). Substituting for $\psi_{i t}$ from condition (11) and imposing symmetry conditions (13), the first-order conditions become:

$$
\begin{gathered}
\ln P_{i t}=\left(\frac{1}{4}\right) E_{t} \sum_{\tau=t}^{t+1} \beta^{\tau}\left[\ln C_{\tau}+\sum_{j \neq i} \frac{1}{N-1} \ln P_{j \tau}+\left(\frac{1}{\gamma}\right)\right] \\
\ln P_{i t}^{*}=\left(\frac{1}{4}\right) E_{t} \sum_{\tau=t}^{t+1} \beta^{\tau}\left[\ln C_{\tau}-\ln S_{\tau}+\sum_{j \neq i} \frac{1}{N-1} \ln P_{j \tau}^{*}+\left(\frac{1}{\gamma}\right)\right]
\end{gathered}
$$

For analytical simplicity, the analysis below will make the approximation of $\beta \approx 1$. Simulations will be used later to demonstrate this approximation has only a very minor effect on the persistence implied by the model.

This implies that a permanent $1 \%$ exchange rate depreciation induces the home firm to lower its price on a product sold in the foreign country by $50 \%$, all else constant. This "pass 
through" coefficient of one-half is a feature of the translog demand equations. ${ }^{9}$ Empirically, this is a reasonable value for the response of price to a change in costs, while holding competitors prices constant. ${ }^{10}$

To simplify the pricing equations, we need to specify the number of home versus foreign products that a typical home firm competes with. To reflect transportation costs or other trade barriers, we will suppose that not all the goods are traded internationally. Thus, the optimization problem specified in (16) applies to a traded variety, while for a non-traded variety only the first part of the objective function (profits from home sales) would appear. Since the profits from home and foreign sales are independent (due to our assumption of constant marginal cost), the choice of home prices in (19) is not affected by whether that good is traded or not.

However, the choice of home prices will be affected by how many of the foreign goods are traded. In particular, suppose that a fraction $\phi$ of all products sold in the home country are produced in the home country, and number these $i=1, \ldots, \phi N$. The remaining varieties $j=\phi N+1, \ldots, N$ are produced in the foreign country and sold at home. We will be supposing that $\phi>1 / 2$, reflecting the presence of some nontraded goods and "home market bias." In steady state, home firms represent a fraction $\phi$ of the home market and a fraction $(1-\phi)$ of the foreign market.

We also must specify the structure of overlapping contracts. In each country we assume there are two equally-sized groups of firms setting prices in two-period contracts in staggered fashion. Home firms in group one choose their prices for the home and foreign markets in period $t$, where $t$ is an odd number, and these prices are then fixed for periods $t$ and $t+1$. Let us denote these prices by $P_{h 1 t}$ and $P_{h 1 t}^{*}$, which are assumed to be the same across all firms in

\footnotetext{
9 This result is invariant to the number of contracting groups and the number of periods in the contract. For a discussion of the general N-period contract case, see Bergin and Feenstra (1998).

10 See Moffet (1988) for a summary of studies with estimates around $50 \%$.
} 
group one. As a group, these firms then represent a fraction $\frac{\phi}{2}$ of the home goods market and a fraction $\frac{1-\phi}{2}$ of the foreign market in steady state. Similarly, the firms in group two choose their prices $P_{h 2 t}$ and $P_{h 2 t}^{*}$ in even periods $t$, which are then fixed for $t$ and $t+1$. The same applies to two groups of firms in the foreign country, setting prices $P_{f 1 t}, P_{f 1 t}^{*}, P_{f 2 t}$ and $P_{f 2 t}^{*}$ in staggered fashion.

Assuming that the total number of firms is large, we can solve for the optimal prices as:

$$
\begin{aligned}
\ln P_{h 1 t}= & \frac{1}{4-\phi} E_{t}\left[\ln C_{t}+\ln C_{t+1}+(1-\phi) \ln P_{f 1 t}+\frac{\phi}{2}\left(\ln P_{h 2 t}+\ln P_{h 2 t+1}\right)\right. \\
& \left.+\frac{1-\phi}{2}\left(\ln P_{f 2 t}+\ln P_{f 2 t+1}\right)+\frac{1}{\gamma}\right] \\
\ln P_{h 1 t}^{*}= & \frac{1}{3+\phi} E_{t}\left[\ln C_{t}+\ln C_{t+1}+\phi \ln P_{f 1 t}^{*}+\frac{1-\phi}{2}\left(\ln P_{h 2 t}^{*}+\ln P_{h 2 t+1}^{*}\right)\right. \\
& \left.+\frac{\phi}{2}\left(\ln P_{f 2 t}^{*}+\ln P_{f 2 t+1}^{*}\right)-\ln S_{t}-\ln S_{t+1}+\frac{1}{\gamma}\right] \\
\ln P_{f 1 t}^{*}=\begin{aligned}
\frac{1}{4-} \\
+
\end{aligned} & \left.\frac{\phi}{2}\left[\ln C_{t}^{*}+\ln P_{f 2 t}^{*}+\ln P_{f 2 t+1}^{*}\right)+\frac{1}{\gamma}\right] \\
& \left.\quad+\frac{1-\phi}{2}\left(\ln P_{f 2 t}+\ln P_{f 2 t+1}\right)+\ln S_{t}+\ln S_{t+1}+\frac{1}{\gamma}\right] \\
\ln P_{f 1 t}= & \frac{1}{3+\phi} E_{t}\left[\ln C_{t}^{*}+\ln C_{t+1}^{*}+\phi \ln P_{h 1 t}^{*}+\frac{\phi}{2}\left(\ln P_{h 2 t}+\ln P_{h 2 t+1}\right)\right. \\
&
\end{aligned}
$$

Of course, an analogous set of four expressions applies to $P_{h 2 t+1}, P_{h 2 t+1}^{*}, P_{f 2 t+1}^{*}$, and $P_{f 2 t+1}$ when $t+1$ is even.

The approximations to the home and foreign price indexes become:

$$
\ln P_{t}=\frac{\phi}{2} \ln P_{h 1 t}+\frac{\phi}{2} \ln P_{h 2 t}+\frac{(1-\phi)}{2} \ln P_{f 1 t}+\frac{(1-\phi)}{2} \ln P_{f 2 t}
$$




$$
\ln P_{t}^{*}=\frac{1-\phi}{2} \ln P_{h 1 t}^{*}+\frac{1-\phi}{2} \ln P_{h 2 t}^{*}+\frac{\phi}{2} \ln P_{f 1 t}^{*}+\frac{\phi}{2} \ln P_{f 2 t}^{*}
$$

\subsection{Pricing to Market and Preferences}

The four price-setting equations above $(21$ - 24) show that home bias in consumption preferences $(\phi)$ plays an important role in generating pricing-to-market behavior by firms. Pricingto-market has been defined in Marston (1990) as the behavior of a firm to intentionally choose different prices for its good in segmented national markets. Consider the case in which we allow our two symmetric countries to have fully open goods markets with no home bias in preferences, so that $\phi=0.5$ and the home market is split evenly between home and foreign producers. In this case pricing equations (21) and (22) are identical, meaning that the home firm sets the same price in the home and the foreign market, once converted to the same currency. In this case the law of one price is satisfied and there is no pricing-to-market. Firms have the ability to set different prices in different markets, but there is no reason to do so if the two markets are identical. For example, a change in marginal costs will be passed on equally to the home and foreign price.

Consider next the case where there is home bias $(\phi>0.5)$. Now home and foreign markets differ in the composition of competitors that a firm faces. In this case a firm faced with a rise in marginal cost will raise price more at home than abroad (by the factor $1 /(4-\phi)$ compared to $1 /(3+\phi))$. The firm feels more free to raise the home price in the face of rising home wages, for example, because it knows that other home firms are affected similarly and will want to raise their prices as well, and these home firms comprise a larger fraction of the competitors in the home market.

Similarly, the translog preference structure, which underlies the pricing equations above, is also important for pricing-to-market. Demand with a non-constant elasticity was assumed in the development of pricing-to-market in Dornbusch (1987), Krugman (1987), Knetter (1989) 
and Marston (1990). Suppose we reconsidered our model using preferences with a constant elasticity of substitution of $\xi$. As is well-known, prices are then a constant markup over marginal cost, so the optimization problem (16) would imply the following pricing rules:

$$
\begin{gathered}
\ln P_{i t}=\frac{1}{2} E_{t}\left[\ln C_{t}+\ln C_{t+1}\right]+\ln \left(\frac{\xi}{\xi-1}\right) \\
\ln P_{i t}^{*}=\frac{1}{2} E_{t}\left[\ln C_{t}+\ln C_{t+1}-\ln S_{t}-\ln S_{t+1}\right]+\ln \left(\frac{\xi}{\xi-1}\right)
\end{gathered}
$$

Competitor's prices do not appear in these two pricing rules. Bergin and Feenstra (1998) argue that such pricing rules cannot give rise to the type of interactions between price setters required for staggered contracts to give rise to endogenous persistence, as envisioned in Taylor(1980) and Blanchard (1983). We further argue here that such pricing rules cannot give rise to genuine pricing-to-market, in that firms will not intentionally choose to set different prices between the two markets. The two pricing rules are identical, except for the currency adjustment. A change in marginal cost $(C)$ will have the same effect on both prices. An anticipated change in the exchange rate $(S)$ will be fully passed through, so that when measured in a common currency, the two prices are identical and the law of one price is satisfied. It is true that if prices are pre-set in the currency of the buyer, an unanticipated change in the exchange rate will drive a temporary wedge between the home and foreign price. Although this phenomenon has sometimes of late been characterized as pricing-to-market, it is distinct from the definition given above, and is best described as "local-currency-pricing" as in Devereux (1997). ${ }^{11}$

\footnotetext{
11 Friberg (1998) has explored conditions under which it is be optimal for firms to invoice in the currency of the importer, as we assume. He likewise finds that a sufficient condition for firms to exhibit such invoicing behavior is that the demand have less convexity than the CES case.
} 


\subsection{Equilibrium Conditions}

For large $N$, the demand functions (12) may be written for each good sold at home:

$$
\begin{gathered}
X_{h t}=\left(\phi+\phi \gamma\left(\ln P_{t}-\ln P_{h t}\right)\right) \frac{P_{t} U_{t}}{P_{h t}} \\
X_{f t}=\left((1-\phi)+(1-\phi) \gamma\left(\ln P_{t}-\ln P_{f t}\right)\right) \frac{P_{t} U_{t}}{P_{f t}}
\end{gathered}
$$

where $X_{h t}$ is demand for the home good by households in the home country and $X_{f t}$ is demand for the foreign good in the home country. (These must also be used in linearized form.) Precisely the same set of expressions holds for foreign demand, where we add an asterisk onto each variable. In addition, analogous sets of expressions hold for domestic and foreign intermediate demands, where we replace the consumption index $U_{t}$ with the intermediate inputs index $Z_{t}$.

Money is introduced by the government as a lump-sum transfer, defined as:

$$
T_{t}=M_{t}-M_{t-1} \text { and } T_{t}^{*}=M_{t}^{*}-M_{t-1}^{*}
$$

It is assumed that money is exogenously supplied.

Equilibrium for this economy is a collection of 31 sequences $\left(P_{h t}, P_{f t}, P_{h t}^{*}, P_{f t}^{*}, P, P^{*}, i\right.$, $i^{*}, W, W^{*}, U, U^{*}, X_{h t}, X_{f t}, X_{h t}^{*}, X_{f t}^{*}, Z_{h t}, Z_{f t}, Z_{h t}^{*}, Z_{f t}^{*}, Z, Z^{*}, Y, Y^{*}, L, L^{*}, B_{h t}, B_{f t}, B_{h t}^{*}$, $B_{f t}^{*}$, and $S_{t}$ ) satisfying 31 equilibrium conditions. ${ }^{12}$ These include the four pricing conditions $(21,22,23,24)$, the definition of the price indexes ( 25 and 26$)$, the four demand equations ( 29 , 30 , and foreign counterparts), six household optimality conditions $(3,4,5$, and foreign counterparts), the risk-sharing condition (6), the two production functions (14 and foreign counterpart), the allocation between intermediates and labor (15 and the foreign counterpart), and four

12 We consolidate the budget constraints of the household, government and firm in each country into two national budget constraints, thereby dropping the variables $T, T^{*}, \Pi$, and $\Pi^{*}$. 
demand equations for intermediates, analogous to those for consumption. ${ }^{13}$ Finally, there are market clearing conditions for the bonds and goods markets:

$$
\begin{gathered}
B_{h t}+B_{h t}^{*}=0 \\
B_{f t}+B_{f t}^{*}=0 \\
X_{h t}+X_{h t}^{*}+Z_{h t}+Z_{h t}^{*}=Y_{h t} \\
X_{f t}+X_{f t}^{*}+Z_{f t}+Z_{f t}^{*}=Y_{f t}^{*}
\end{gathered}
$$

Under incomplete markets, condition (6) is replaced by (8).

\section{Results}

\subsection{Solving Analytically}

We now evaluate the effects of combining pricing-to-market with staggered contracts under a translog demand structure. To facilitate an analytical solution, we initially choose convenient values for parameters in the utility function. In particular, we consider a benchmark case where $\sigma_{1}=\sigma_{2}=1$ and $\sigma_{3}=0$. This produces the same utility formulation as used for analytical results in Obstfeld and Rogoff (1995). ${ }^{14}$ Under the assumption of $\sigma_{1}=\sigma_{2}=1$, the

13 The household problem implies two pairs of redundant equations regarding the holding of home and foreign bonds. The redundancy is dealt with by introducing two arbitrary bond allocation rules, suggesting that households adjust their holdings of home and foreign bonds in a fixed proportion.

14 This has the implication of an infinite labor supply elasticity. But this will be demonstrated later to have a negligible effect on persistence in the present model. 
linearized forms of (3) and (4) jointly imply: ${ }^{15}$

$$
E_{t}\left[p_{t+1}+u_{t+1}\right]=\frac{1}{\beta}\left[p_{t}+u_{t}\right]-\frac{1-\beta}{\beta} m_{t}
$$

where we use lower case letters to represent percent deviations from the initial deterministic steady state. This is a difference equation in nominal expenditure $\left(p_{t}+u_{t}\right)$, with the stable solution:

$$
p_{t}+u_{t}=m_{t}
$$

This implies that a permanent one percent increase in money supply translates into an equal permanent one percent increase in nominal expenditure. The initial impact on real final output, $u_{t}$, depends on the degree to which the price level can respond. And the persistence of this real effect depends on the dynamics of the price level (25) and hence on the price-setting rules (21 - 24). In an analogous manner, the same can be shown for foreign real final output, $u_{t}^{*}$.

This conclusion can also be demonstrated for the real exchange rate. In linear form, the risk-sharing condition (6) implies:

$$
u_{t}-u_{t}^{*}=s_{t}+p_{t}^{*}-p_{t}=q_{t}
$$

where the right-hand side of this equation defines the percent change in the real exchange rate. Since the dynamics of $u_{t}$ and $u_{t}^{*}$ depend entirely on the dynamics of the price-setting rules, condition (38) implies this is true also for the real exchange rate.

Therefore, to gain insight into the persistence of both output and the real exchange rate, we study the dynamics of the price-setting rules. These rules can be expressed in a simplified form. First, under the assumption that $\sigma_{3}=0$ the linearized form of the labor supply condition

15 Linearization of the model is not necessary for all the conclusions that follow. 
(5) implies in combination with (37) that:

$$
w_{t}=p_{t}+u_{t}=m_{t}
$$

As a result, the marginal cost term in the pricing equations, $c_{t}$, may be expressed in terms of the goods prices themselves and the exogenous money shock:

$$
c_{t}=\theta w_{t}+(1-\theta) p_{t}=\theta m_{t}+(1-\theta) p_{t}
$$

Secondly, condition (38) implies that the nominal exchange rate likewise can be expressed in terms of the money supply shocks:

$$
s_{t}=\left(u_{t}+p_{t}\right)-\left(u_{t}^{*}+p_{t}^{*}\right)=m_{t}-m_{t}^{*}
$$

The four pricing equations $(21,22,23,24)$ then may be expressed as a system of four equations in four endogenous price variables and the exogenous money shocks.

We wish to consider the model's response to a domestic money shock. While it is not feasible to solve analytically for the dynamics of each price individually, we can solve for the dynamics of two especially useful linear combinations of these prices. Define the sum of national prices, $\pi_{1 t}$, and the difference of national prices, $\pi_{2 t}$ :

$$
\begin{aligned}
& \pi_{1 t}=\left[\phi p_{h 1 t}+(1-\phi) p_{f 1 t}\right]+\left[\phi p_{f 1 t}^{*}+(1-\phi) p_{h 1 t}^{*}\right] \\
& \pi_{2 t}=\left[\phi p_{h 1 t}+(1-\phi) p_{f 1 t}\right]-\left[\phi p_{f 1 t}^{*}+(1-\phi) p_{h 1 t}^{*}\right]
\end{aligned}
$$

The appendix uses standard methods to show that the dynamics of these may be written as

$$
\begin{aligned}
& \pi_{1, t}=a_{1} \pi_{1, t-1}+\left(1-a_{1}\right) m_{t} \\
& \pi_{2, t}=a_{2} \pi_{2, t-1}+\left(1-a_{2}\right) m_{t}
\end{aligned}
$$


where

$$
\begin{gathered}
a_{1}=\frac{\sqrt{2}-\sqrt{\theta}}{\sqrt{2}+\sqrt{\theta}} \\
a_{2}=\left(\frac{4-2 \phi(1-\theta)-\theta}{2 \phi(1-\theta)+\theta}\right)-\left(\left(\frac{4-2 \phi(1-\theta)-\theta}{2 \phi(1-\theta)+\theta}\right)^{2}-1\right)^{\frac{1}{2}}
\end{gathered}
$$

The term $a_{1}$ is the same autoregressive term found for the case of a single closed economy in Bergin and Feenstra (1998). This term depends negatively on $\theta$, the share of labor in marginal costs, because the rise in marginal costs induces firms to raise price as they raise production. See Bergin and Feenstra (1998) for a discussion. The term $a_{1}$ has a useful interpretation as the persistence in total world output. Writing the world price index as $p_{t}^{w}=\frac{1}{4}\left(\pi_{1, t}+\pi_{1, t-1}\right)$, its dynamics are:

$$
p_{t}^{w}=a_{1} p_{t-1}^{w}+\frac{1}{4}\left(1-a_{1}\right)\left(m_{t}+m_{t-1}\right)
$$

World output may be written in percent deviations as:

$$
u_{t}^{w}=\frac{1}{2}\left(p_{t} u_{t}+p_{t}^{*} u_{t}^{*}\right)-p_{t}^{w}
$$

Since the percent deviation in world nominal expenditure was shown to be equal to the deviation in nominal money, output deviations may be written as the following autoregression:

$$
u_{t}^{w}=a_{1} u_{t-1}^{w}+\frac{1}{4}\left(1+a_{1}\right)\left(m_{t}-m_{t-1}\right)
$$

The term $a_{1}$ is a useful measure of persistence in output movements. It is interpretable as both the first-order first-order autoregressive coefficient and as the first-order autocorrelation.

The term $a_{2}$ has an analogous interpretation as the persistence of the real exchange rate. 
In percent deviations, the real exchange rate may be written:

$$
q_{t}=s_{t}-\frac{1}{2}\left(\pi_{2, t}+\pi_{2, t-1}\right)
$$

so that

$$
q_{t}=a_{2} q_{t-1}+\frac{1}{2}\left(1+a_{2}\right)\left(m_{t}-m_{t-1}\right)
$$

The term $a_{2}$ is the first-order autoregressive coefficient for real exchange rate deviations, as well as an autocorrelation coefficient which may be compared to that reported in Table 1 for actual data.

Much of the analysis above still applies under incomplete markets. The long-run steady state is altered a small amount due to transfers of wealth between home and foreign households. The term $a_{1}$ is still the autocorrelation of total output, but $a_{2}$ must be interpreted as the autocorrelation relative to the new long-run steady state rather than the initial steady state. See the appendix for details.

\subsection{Implications for Persistence}

Note that for the persistence indicators $a_{1}$ and $a_{2}$ derived above, it is true that $a_{2} \leq a_{1}$. This indicates that persistence in the real exchange rate is less than that in real final output. Only in the special case of complete home bias, $\phi=1$, do we have the two persistence indexes coinciding. And as home bias falls, the persistence in the real exchange rate falls. This implies that the degree of persistence in the real exchange rate is dampened by the degree of "openness" in an economy.

This finding may be explained in more intuitive terms. The permanent depreciation in the nominal exchange rate translates into a real depreciation only to the degree that the price indexes in each country do not adjust in an offsetting way. However, the pricing equations (21 
- 24) imply that the components of the price indexes will respond more strongly to a nominal devaluation if there is a greater degree of openness. For example, equation (24) indicates that foreign producers will raise the price they charge in the home country when the home currency depreciates. If foreign goods play a larger role in the home consumption basket, the overall home price index will rise more. In addition, if foreign goods represent a larger fraction of competitors in the home market, home producers will tend to raise their price in response. This will further raise the home price index, offsetting the impact on the real exchange rate. ${ }^{16}$

Nevertheless, the model can generate significant persistence for some choices of the parameters. Figure 1 depicts how the autocorrelation, $a_{2}$, varies as a function of home bias, $\phi$, and the share of labor in marginal cost, $\theta$. The share of intermediates is $1-\theta$. The figure shows that it is theoretically possible to generate nearly perfect persistence, with an autocorrelation of approximately 1.0. But this requires that the economy approaches autarky, and that materials comprise the entirety of marginal costs $(\phi \approx 1.0, \theta=0)$. What are reasonable values for these two parameters? First regarding home bias, data on the ratio of U.S. imports to GDP indicate a value of $\phi=0.85$.

Second, Basu (1995) recommends a value for $\theta$ between 0.10 and 0.20 . This is based on work by Jorgenson et al. (1987) estimating that the share of intermediates in total output is $50 \%$ or more. Basu (1995) transforms this ratio into $1-\theta$, the ratio of expenditure on inputs to total costs, using an estimate of the markup of 1.6 by Domowitz et al. (1988). Our model does not have a constant markup, but in steady state this markup will be $\frac{1+\gamma}{\gamma}$. By setting $\gamma$ to be 2 , the model implies a steady state markup of 1.5 .

Table 2 lists the autocorrelations implied by various levels of $\theta$, once the home bias has been fixed at $\phi=0.85$. We can interpret each period of the model as a year and aim to

16 This finding does not offset persistence in world output, because this involves the sum of national price indexes, which are affected in opposing directions and thus cancel. 
match the annual autocorrelation of 0.27 reported for the data in Table 1 . Table 2 indicates that intermediates play an essential role in achieving reasonable persistence. Note that the model can match the autocorrelation in the data for any value of $\theta$ under one-half, and any value in the range recommended by Basu $(0.1<\theta<0.2)$ produces more than enough persistence. For example, the case of $\theta=0.15$ implies an autocorrelation of $a_{2}=0.38$. Further, this persistence is achieved with a reasonable degree of exogenous price stickiness. Interpreting each period as a year, our model fixes prices exogenously for only one year, at which point all price setters have had a change to reset their price at least once. ${ }^{17}$ By contrast, Chari, et.al. (1998a) require that prices be fixed exogenously for at least three years to approach the exchange rate persistence in the data.

As noted previously, a distinct but related time-series literature indicates a much higher degree of real exchange rate persistence, compared to the serial correlations typically used as a benchmark in the theoretical literature. Time-series studies have estimated a half-life of at least four to five years for the real exchange rate as it returns to its mean, and some indicate the real exchange rate may not be mean reverting at all. As discussed in the appendix, the version of our model with incomplete asset markets technically can generate a real exchange rate that is not mean-reverting. However, the permanent effect on the real exchange rate is small relative to the initial impact, as will be discussed below, and this has a quantitatively insignificant impact on the serial correlation and the half-life. Replicating the results of the time-series literature, unfortunately, is beyond the scope of the present paper.

We can gain further intuition for the endogenous persistence by considering model simulations. The model is analyzed in linear form, in percent deviations from steady state. The

17 If we use data that is not Hodrick-Prescott filtered, the average annual autocorrelation in the real exchange becomes 0.71 . To replicate this higher benchmark, we would need to interpret each period in the model as between two and three years in duration, and likewise impose exogenous price rigidity lasting two to three years. 
steady state affects this linearization only through the goods market clearing condition, which depends on the steady-state share of intermediates in total production. This may be computed:

$$
\frac{\bar{Z}}{\bar{Y}}=(1-\theta) \frac{\gamma}{1+\gamma}
$$

We begin by calibrating the model with benchmark parameters. We set $\theta=0.15$, in the center of the range recommended by Basu (1995). To be consistent with this, $\gamma$ is set at 2 . In addition, we set $\phi=0.85$, as indicated by U.S. data for imports relative to GDP. To begin with, we use the preference parameters used for analytical solution $\left(\sigma_{1}=\sigma_{2}=1, \sigma_{3}=0, \beta \approx 1\right)$.

Our calibration of $\gamma=2.0$ implies a demand elasticity in steady state of $1+\gamma=3$, which is not unreasonable. By contrast, the demand elasticity assumed by Kimball (1995) for his demand curve is 11. Kimball's demand has been criticized by Chari, Kehoe and McGrattan, (1998b) as implying an unreasonable degree of curvature. In particular, it is found that a 2 percent increase in relative price results in a 78 percent reduction in Kimball's demand relative to steady state, and a 2.3 percent increase in relative price results in zero demand. This may be contrasted with the translog demand used in the present paper:

$$
X_{i t}^{h}=\psi_{i t} \frac{P_{t} U_{t}}{P_{i t}}=\left[\frac{1+\gamma\left(\overline{\ln P_{j t}}-\ln P_{i t}\right)}{P_{i t}}\right] \frac{P_{t} U_{t}}{N}
$$

where $\overline{\ln P_{j t}}=\sum_{j \neq i} \ln P_{j t} /(N-1)$ represents the average price set by competitors in the market. This implies that a 2 percent rise in the relative price of good $i$ from steady state lowers demand by only 5 percent, and a 3 percent rise in relative price lowers demand by $8.7 \%$. We conclude that the criticism of Kimball's demand structure does not apply here; the translog form implies a very reasonable degree of curvature.

Figure 2 shows impulse responses in exchange rates and prices to the permanent onepercent increase in home money supply. Again interpreting each period in the model as one year, it is one year after the shock before both groups of price setters in each country have had 
a chance to reset their prices. Endogenous persistence then is the fraction of the effect in the initial period of the shock that persists one year later. On impact of the shock, the nominal exchange rate jumps immediately to its new long-run level of one percent above its initial steady state level. The ratio of home to foreign price levels rises $31 \%$, so the real exchange rate depreciates $69 \%$. One year after the shock, the real exchange rate is still depreciated $26 \%$, meaning that $38 \%$ of the initial impact still persists once all firms have had a chance to reset their prices. This confirms the first-order autocorrelation predicted by equation (47).

We can also observe the effect of the monetary shock on pricing-to-market. Consider a measure of pricing-to-market, $s_{t}+p_{h t}^{*}-p_{h t}$, which is the foreign price of the home good converted to home currency units as a ratio to the domestic price of the home good. This measure increases $62 \%$ relative to steady state on impact and $16 \%$ in the subsequent period, so that $27 \%$ of the initial impact persists.

Figure 3 shows responses in home and foreign output and the trade balance. Because the money demand elasticity with respect to consumption is unity, nominal expenditure on final output necessarily rises one percent. Part of this increased expenditure falls on imported goods, so foreign output rises, though by a smaller magnitude because of the home bias in consumption. Because the home price level adjusts $26 \%$ on impact, real final output rises by $74 \%$. One year after the shock, once all firms have had a chance to reset their prices, still $48 \%$ of the initial impact on home output persists. ${ }^{18}$

Analysis by simulation is no longer restricted to the simplifying assumptions necessary for analytical solution. First, it is instructive to use simulations to confirm that the assumption of incomplete markets is innocuous in the present context. Under the benchmark parameters, limiting asset trade to noncontingent debt, a one-percent increase in home money causes a

18 Note that the autoregressive expression (49) applies to total world output, not to home output alone, which does not follow a first-order autoregression in the model. 
long-run appreciation in the exchange rate. However, the magnitude is only $0.6 \%$, two orders of magnitude smaller than the impact effect on the real exchange rate. Further, the coefficient $a_{2}=0.38$ still measures the constant first-order autoregressive coefficient of the real exchange rate as it decays toward its new long-run steady state, if this is measured in percent deviations from its new long-run steady state.

Second, it is instructive to confirm that the simplifying assumption of $\sigma_{3}=0$ is innocuous. If just the value of $\sigma_{3}$ is changed to the more plausible value of unity, the first-order autoregressive coefficient for the real exchange rate falls only a small amount, from 0.38 to 0.35 .

Lastly we confirm that our simplifying approximation of $\beta \approx 1$ is innocuous. If instead we use $\beta=0.96$, the autoregressive coefficient for the real exchange rate falls only from 0.38 to 0.37 .

\subsection{Volatility}

In addition to persistence, another prominent feature of movements in the real exchange rate is that they are rather large. Table 1 indicates that the volatility of the real exchange rate is between four to five times that in output. This is often attributed to exchange rate overshooting, a la Dornbusch (1976). Under the benchmark parameterizations of the model above, there is no overshooting in response to the monetary shock. Given that the increase in nominal expenditure equals the increase in money, as shown above, then the money demand equation (4) implies that the nominal interest rate is unchanged from its steady state. The interest rate parity condition (7) then implies that $s_{t+1}=s_{t}$ for all $t$, that the exchange rate jumps immediately to its new long-run level.

Overshooting can be introduced by considering a more careful parameterization of preferences related to money demand. The parameterization in the benchmark case assumes that 
the interest elasticity of real money balances, $1 / \sigma_{2}$, is unity. Empirical studies find a wide range of estimates: from 0.39 in Chari et al. (1998a) to 0.05 in Mankiw and Summers (1986). We choose an intermediate value of $0.2\left(\sigma_{2}=5\right)$. Empirical studies estimate that the income elasticity of real money demand $\left(\sigma_{1} / \sigma_{2}\right.$ here) is about unity, so we also set $\sigma_{2}=5$. This implies that the elasticity of intertemporal substitution in consumption is 0.2 . This is low but is not outside the wide range of values found by empirical studies. Our alternative parametrization will also use the more plausible value of unity for $\sigma_{3}$, discussed previously.

Under this parameterization, it is no longer true that interest rates are unaffected by the monetary shock. If the home interest rate falls relative to the foreign interest rate, equilibrium in the bond market requires that bond holders expect a future appreciation in the home currency. This implies that the depreciation on impact of the shock overshoots the long run level. Figure 4 shows that under this alternative parametrization the nominal exchange rate overshoots by $15 \%$. The real exchange rate depreciation on impact is now $82 \%$, higher than the $69 \%$ seen previously. Further, the response in domestic output on impact has been dampened to $0.19 \%$, compared to $74 \%$ previously. As a result, the volatility of the real exchange rate in the period of the shock now is between 4 and 5 times that in output, as seen in the data.

In addition, volatility interacts with persistence in two interesting ways. First volatility seems to lower persistence. Simulation under the alternative parameterization still produces a constant value for the autocorrelation of the real exchange rate, though here it is 0.31 , lower than the value of 0.38 in the benchmark case without overshooting. Recall the preceding argument that openness reduces real exchange rate persistence by causing the relative price indexes to adjust more quickly to a nominal devaluation. Here the fact that the nominal devaluation is larger amplifies this tendency for price indexes to change, and thus to further undercut real exchange rate persistence. Table 3 lists the autocorrelation for various choices of $\sigma_{1}$ and $\sigma_{2}$.

A second interaction is that persistence seems to amplify volatility in the model. For 
example, persistence can be raised from $0.17 \%$ to $0.38 \%$ by changing $\theta$ from unity to 0.15 . This increased persistence raises overshooting from $10 \%$ to $15 \%$. Intuitively, if the home interest rate remains below the foreign counterpart for more periods, the domestic currency must be expected to depreciate for several periods consecutively. As a result the initial overshooting must be more extreme than if the interest differential were not persistent. This point has been discussed by Chadha (1987) in the context of exogenous persistence.

\section{Conclusion}

The focus of this paper has been to seek an explanation for the high degree of persistence observed in the real exchange rate. It is found that staggered price contracts combined with pricing-to-market are able to generate significant persistence beyond the exogenously imposed rigidity. Translog preferences are important for amplifying the effects of both these mechanisms. The autocorrelation implied by the model replicates that exhibited in the data. However, to some degree openness in the economy limits the degree of persistence in the real exchange rate.

The paper has also considered the model's implications for exchange rate volatility. It is found that significant volatility can be replicated in the present model under reasonable parameter values which generate exchange rate overshooting. In addition, volatility in the real exchange rate is found to interact with persistence in two ways: while volatility further limits the degree of persistence, the degree of persistence somewhat amplifies the degree of volatility.

In general, the model lends support to the idea that macroeconomic fundamentals can help explain real exchange rate behavior, at least in the long run. Further, the model helps explain why this long run is so far away. 


\section{Appendix}

The dynamics of the system of price-setting equations $(21,22,23,24)$ may be characterized as follows. Defining the terms:

$$
\begin{aligned}
& \pi_{t}=\phi p_{h 1 t}+(1-\phi) p_{f 1 t} \\
& \pi_{t}^{*}=\phi p_{f 1 t}^{*}+(1-\phi) p_{h 1 t}^{*}
\end{aligned}
$$

the four price setting equations may be combined and written as:

$$
\left[\begin{array}{l}
\pi_{t} \\
\pi_{t}^{*}
\end{array}\right]=F\left\{\left[\begin{array}{l}
\pi_{t-1} \\
\pi_{t-1}^{*}
\end{array}\right]+2\left[\begin{array}{l}
\pi_{t} \\
\pi_{t}^{*}
\end{array}\right]+E_{t}\left[\begin{array}{c}
\pi_{t+1} \\
\pi_{t+1}^{*}
\end{array}\right]\right\}+G E_{t}\left(m_{t+1}+m_{t+2}\right)
$$

where

$$
F=\frac{1}{8}\left[\begin{array}{cc}
\phi(2-\theta)+1-\phi & (1-\theta)(1-\phi) \\
(1-\theta)(1-\phi) & \phi(2-\theta)+1-\phi
\end{array}\right]
$$

and

$$
G=\frac{1}{4}\left[\begin{array}{c}
\phi \theta+(1-\phi) \\
(1-\phi)(\theta-1)
\end{array}\right]
$$

Using standard methods, the solution to this matrix difference equation is,

$$
\left[\begin{array}{l}
\pi_{t} \\
\pi_{t}^{*}
\end{array}\right]=H\left[\begin{array}{c}
\pi_{t-1} \\
\pi_{t-1}^{*}
\end{array}\right]+H(I-H L)^{-1} F^{-1} G E_{t}\left(m_{t+1}+m_{t+2}\right)
$$


where $L$ is the lead operator, and $H$ is the matrix,

$$
H=\frac{1}{2}\left(F^{-1}-2 I\right) \pm \frac{1}{2}\left[\left(F^{-1}-2 I\right)^{2}-4 I\right]^{1 / 2}
$$

Assuming that the money supply follows a random walk, then this solution is simplified as,

$$
\left[\begin{array}{l}
\pi_{t} \\
\pi_{t}^{*}
\end{array}\right]=H\left[\begin{array}{c}
\pi_{t-1} \\
\pi_{t-1}^{*}
\end{array}\right]+2 H(I-H)^{-1} F^{-1} G m_{t}
$$

In order to convert this two-variable system to a univariate equation, we pre-multiply by the eigenvectors of $H$, which are the same as the eigenvectors of $F$. By inspection, these are the vectors $v_{1}=(1,-1)$ and $v_{2}=(1,1)$. Pre-multiplying the system above by $v_{1}$ yields

$$
\pi_{1, t}=a_{1} \pi_{1, t-1}+\left(1-a_{1}\right) m_{t}
$$

while pre-multiplying by $v_{2}$ yields

$$
\pi_{2, t}=a_{2} \pi_{2, t-1}+\left(1-a_{2}\right) m_{t}
$$

where $\pi_{1, t}=\pi_{t}+\pi_{t}^{*}, \pi_{2, t}=\pi_{t}-\pi_{t}^{*}$, and $a_{1}$ and $a_{2}$ are the respective eigenvalues of $H$.

Here $a_{1}$ is the solution to the equation:

$$
a_{1}^{2}-\left(\left(\frac{8}{2-\theta}\right)-2\right) a_{1}+1=0
$$

which is (46). Similarly, $a_{2}$ is the solution to the equation:

$$
a_{2}^{2}-\left(\left(\frac{8}{2 \phi(1-\theta)+\theta}\right)-2\right) a_{2}+1=0
$$

which is (47).

Alternatively, under the assumption of incomplete markets, the analysis changes as follows. Because the risk-sharing condition (6) no longer holds, it is no longer true that the 
nominal exchange rate change equals that in money. Nevertheless, they move in a constant proportion. Because there is no change in the nominal interest rate under the benchmark parameters, the interest rate parity condition (7) implies that the nominal exchange rate moves immediately to its new long-run level. Defining $\delta$ as the constant ratio $\frac{s}{m}$, the system of four pricing equations may still be written as in (57), with the change that:

$$
G=\frac{1}{4}\left[\begin{array}{c}
\phi \theta+(1-\phi) \delta \\
(1-\phi)(\theta-\delta)
\end{array}\right]
$$

The analysis of real exchange rate dynamics still applies, except that now

$$
q_{t}=a_{2} q_{t-1}+\frac{1}{2}\left(1+a_{2}\right)\left(m_{t}-m_{t-1}\right)+(\delta-1)\left(m_{t}-a_{2} m_{t-1}\right)
$$

The term $a_{2}$ still indicates a measure of persistence in real exchange rate deviations resulting from a home money shock, once this is adjusted for the permanent effect to the steady state (which equals $\left(1-a_{2}\right)(\delta-1)$ ). 


\section{References}

Backus, David, Patrick Kehoe and Finn Kydland, 1992, "International Real Business Cycles," Journal of Political Economy, 745-775.

Basu, Susanto, 1995, "Intermediate Goods and Business Cycles: Implications for Productivity and Welfare," American Economic Review, 85:3, June, 512-531.

Bergin, Paul R. and Robert C. Feenstra, 1998, "Staggered Price Setting, Translog Preferences, and Endogenous Persistence" mimeo, University of California, Davis, December.

Betts, Caroline, and Michael Devereux, 1996, "The Exchange Rate in a Model of Pricing-toMarket," European-Economic-Review, 40(3-5), April, 1007-21.

Betts, Caroline, and Michael Devereux, 1998, "Exchange Rate Dynamics in a Model of Pricingto-Market," 1997, forthcoming in Journal of International Economics.

Blanchard, Olivier J., 1983, "Price Asynchronization and Price Level Inertia." in Inflation, Debt, and Indexation, ed. by R. Dornbusch and M. H. Simonsen. Cambridge, Mass: MIT Press.

Chadha, Binky (1987), "Contract Length, Monetary Policy and Exchange Rate Variability," Journal of International Money and Finance, 6(4), December, 491-504.

Chang, Roberto, and Michael Devereux, 1998, "Dynamic Collusion, Pricing to Market, and Real Exchange Rates," mimeo, University of British Columbia, June.

Chari, V.V., Patrick Kehoe and Ellen McGrattan, 1998a, "Monetary Shocks and Real Exchange Rates in Sticky Price Models of International Business Cycles," Staff Report 223, Federal Reserve Bank of Minneapolis, December.

Chari, V.V., Patrick Kehoe and Ellen McGrattan, 1998b, "Sticky Price Models of the Business Cycle: Can the Contract Multiplier Solve the Persistence Problem," mimeo, Federal Reserve Bank of Minneapolis, Research Department Staff Report 217, May.

Devereux, Michael B., 1997, "Real Exchange Rates and Macroeconomics: Evidence and Theory," Canadian Journal of Economics, 30, 773-808.

Devereux, Michael B. and Charles Engel, 1998, "Fixed vs. Floating Exchange Rates: How Price Setting Affects the Optimal Choice of Exchange-Rate Regime," NBER Working Paper 6867, December.

Domowitz, Ian, R. Glenn Hubbard, and Bruxe C. Petersen, 1988, "Market Structure and Cyclical Fluctuations in U.S. Manufacturing," Review of Economics and Statistics, February, 70(1), $55-66$.

Dornbusch, Rudiger, 1976, "Expectations and Exchange Rate Dynamics,” Journal of Political 
Economy, 84, 1161-1177.

Dornbusch, Rudiger, 1987, "Exchange Rates and Prices, American Economic Review, 77, 93106.

Engel, Charles, 1993, "Real Exchange Rates and Relative Prices: An Empirical Investigation," Journal of Monetary Economics, 32, 35-50.

Engel, Charles, 1999, "Long-Run PPP May Not Hold After All," forthcoming in Journal of International Economics.

Friberg, Richard, 1998, "In Which Currency Should an Exporter Set His Price?”, Journal of International Economics, 45, 59-76.

Froot, Kenneth, and Kenneth Rogoff, 1995, "Perspectives on PPP and Long-Run Real Exchange Rates," in Grossman,-Gene-M.; Rogoff,-Kenneth, eds. Handbook of International Economics. Volume 3, New York: Elsevier, North-Holland, 1647-88.

Jorgenson, Dale W., Frank M. Gollop, and Barbara M. Fraumeni, 1987, Productivity and U.S. Economic Growth, Cambridge, MA: Harvard, University Press.

Kimball, Miles S., 1995, "The Quantitative Analytics of the Basic Neomonetarist Model ", Journal of Money, Credit, and Banking ; 27(4), Part 2, 1241-77.

Knetter, Michael, 1989, "Price Discrimination by U.S. and German Exporters, American Econmic Review, 79, 198-210.

Knetter, Michael, 1993, "International Comparisons of Price-to-Market Behavior," American Economic Review, 83, 473-486.

Kollmann, Robert, 1996, "The Exchange Rate in a Dynamic-Optimizing Current Account Model with Nominal Rigidities: A Quantitative Investigation.” Working Paper: University of Montreal.

Krugman, Paul R., 1987, "Pricing to Market When the Exchange Rate Changes. In S.W. Arndt and J.D. Richardson, eds,. Real Financial Linkages Among Open Economies. Cambridge Mass: MIT Press.

Mankiw, N. Gregory and Lawrence H. Summers, 1986, "Money Demand and the Effects of Fiscal Policies," Journal of Money, Credit and Banking 18, 415-29.

Marston, Richard, C., 1990, "Pricing to Market in Japanese Manufacturing," Journal of International Economics, 29, 217-136.

Moffett, Michael H., 1989, "The J-curve Revisted: An Empirical Examinatinfor the United States.” Journal of International Money and Finance, 8 (3), September, 425-44. 
Obstfeld, Maurice and Kenneth Rogoff, 1995, "Exchange Rate Dynamics Redux," Journal of Political Economy, 103, 624-660.

Svensson, Lars E.O. and Sweder van Wijnbergen, 1989, "Excess Capacity, Monopolistic Competition, and International Transmission of Monetary Disturbances," Economic Journal, 99, 785-805.

Taylor, John B., 1998, "Staggered Price and Wage Setting in Macroeconomics," NBER Working Paper 6754. 


\section{Table 1: Basic Data}

Autocorrelation: Real Exchange Rate

\begin{tabular}{|c|c|c|c|c|c|c|c|}
\hline & Canada & France & Germ. & Italy & Japan & U.K. & Average \\
\hline 1 qtr. & 0.88 & 0.78 & 0.74 & 0.79 & 0.81 & 0.79 & 0.80 \\
\hline 4 qtr & 0.34 & 0.25 & 0.25 & 0.21 & 0.28 & 0.27 & 0.27 \\
\hline
\end{tabular}

Autocorrelation: Real GDP

\begin{tabular}{|c|c|c|c|c|c|c|c|}
\hline & Canada & France & Germ. & Italy & Japan & U.K. & Average \\
\hline 1 qtr. & 0.89 & 0.84 & 0.74 & 0.83 & 0.67 & 0.85 & 0.80 \\
\hline 4 qtr. & 0.29 & 0.21 & 0.24 & -0.04 & 0.12 & 0.44 & 0.21 \\
\hline
\end{tabular}

Standard Deviation

\begin{tabular}{|l|c|c|c|c|c|c|c|}
\hline & Canada & France & Germ. & Italy & Japan & U.K. & Average \\
\hline RER / GDP & 2.05 & 7.57 & 4.35 & 4.26 & 5.87 & 4.79 & 4.81 \\
\hline
\end{tabular}

All data are quarterly series from IFS, 1973:1 - 1997:3. Series are logged and Hodrick-Prescott filtered. The real exchange rate is computed as the CPI-adjusted nominal exchange rate. 


\section{Real Exchange Rate Autocorrelations Analytical Solution*}

Figure 1: Range of values for $\phi$ and $\theta$

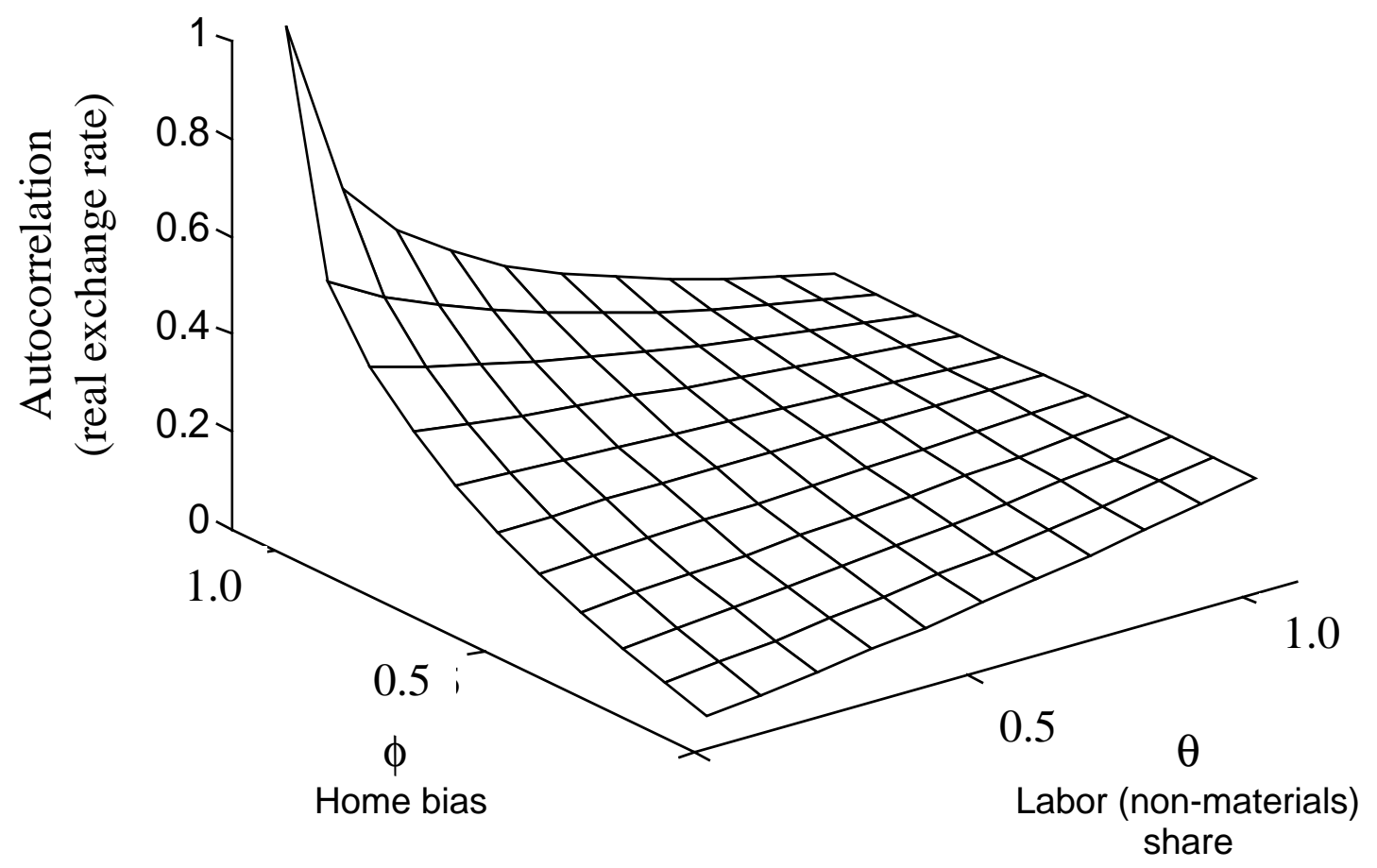

Table 2: Case of $\phi=0.85$

\begin{tabular}{|c|c|c|}
\hline$\theta$ & $\begin{array}{c}\text { Autocorrelation } \\
\text { RER }\end{array}$ & $\begin{array}{c}\text { Autocorrelation } \\
\text { GDP }\end{array}$ \\
\hline 0 & 0.44 & 1.00 \\
\hline 0.1 & 0.40 & 0.63 \\
\hline 0.15 & 0.38 & 0.57 \\
\hline 0.2 & 0.36 & 0.52 \\
\hline 0.5 & 0.27 & 0.33 \\
\hline 1.0 & 0.18 & 0.17 \\
\hline
\end{tabular}

*Parameters: sigma1 $=$ sigma2 $=1$, sigma3 $=0$ 


\section{Table 3: Simulation Results}

Range of Values for Preference Parameters Benchmark Parameters*

\begin{tabular}{|c|c|c|}
\hline$\sigma_{1}=\sigma_{2}=$ & $\begin{array}{c}\text { Autocorrelation } \\
\text { RER }\end{array}$ & $\begin{array}{c}\text { Autocorrelation } \\
\text { GDP }\end{array}$ \\
\hline 0.1 & 0.39 & 0.58 \\
\hline 0.5 & 0.39 & 0.58 \\
\hline 1.0 & 0.38 & 0.57 \\
\hline 5 & 0.33 & 0.52 \\
\hline 10 & 0.29 & 0.48 \\
\hline
\end{tabular}

*Para

meters: $\phi=0.85, \theta=0.15, \beta=0.96, \gamma=2, \sigma_{3}=0$. 


\section{Figure 2: Exchange Rate Responses BenchmarkParameterization*}

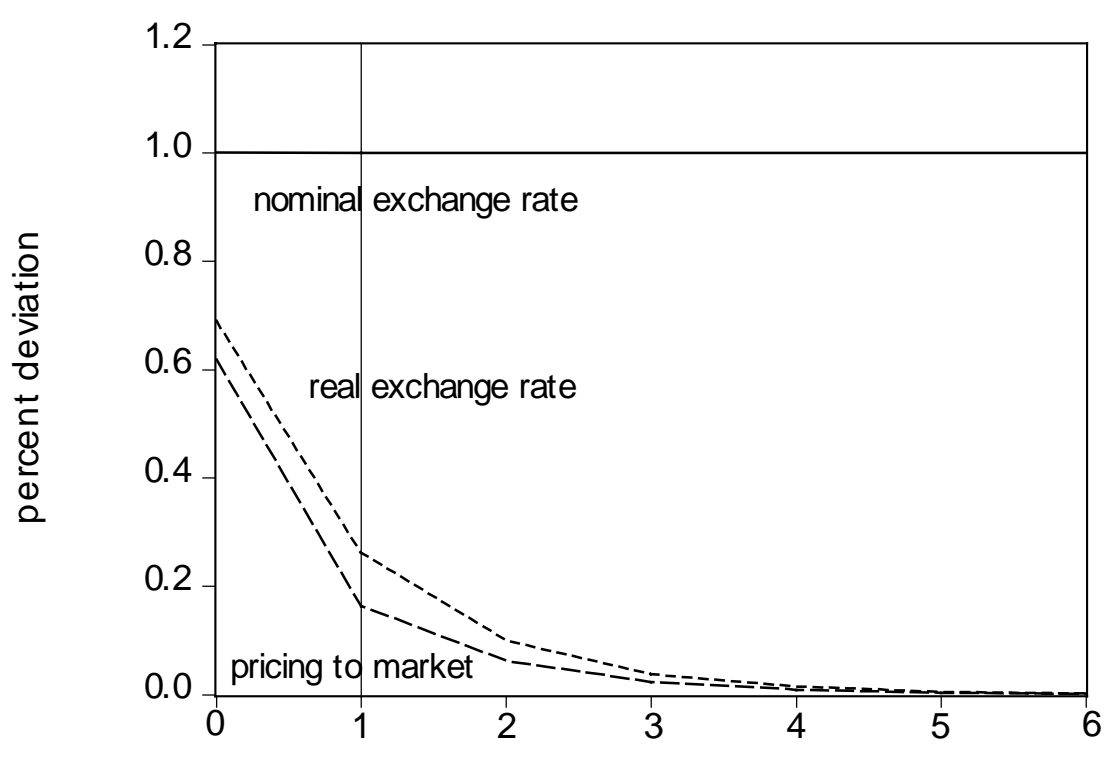

Years after monetary shock

Response to a permanent $1 \%$ increase in nominal money supply. One group resets price in initial period; both groups have resetprice one year after shock.

${ }^{*}$ Parameters: $\operatorname{sigma} 1=\operatorname{sigma} 2=1, \operatorname{sigma} 3=0$, theta $=0.85$, phi $=0.15$, gamma $=2$, beta $=0.96$. 
Figure 3: Quantity Responses Benchmark Parameterization*

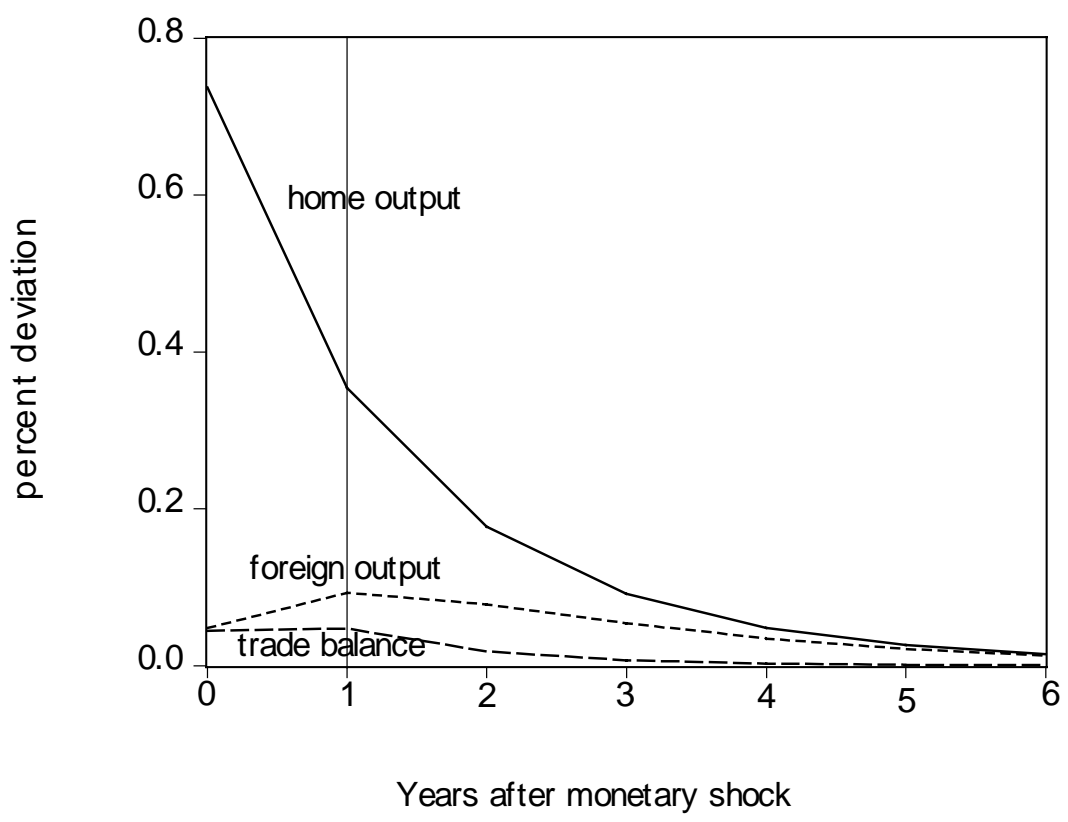

Response to a permanent $1 \%$ increase in nominal money supply . One group resets price in initial period; both groups have resetprice one year after shock.

*Parameters: sigma $1=\operatorname{sigma} 2=1$, sigma $3=0$, theta $=0.85$, phi $=0.15$, gamma $=2$, beta $=0.96$. 


\section{Figure 4: Exchange Rate Responses Alternative Parameterization*}

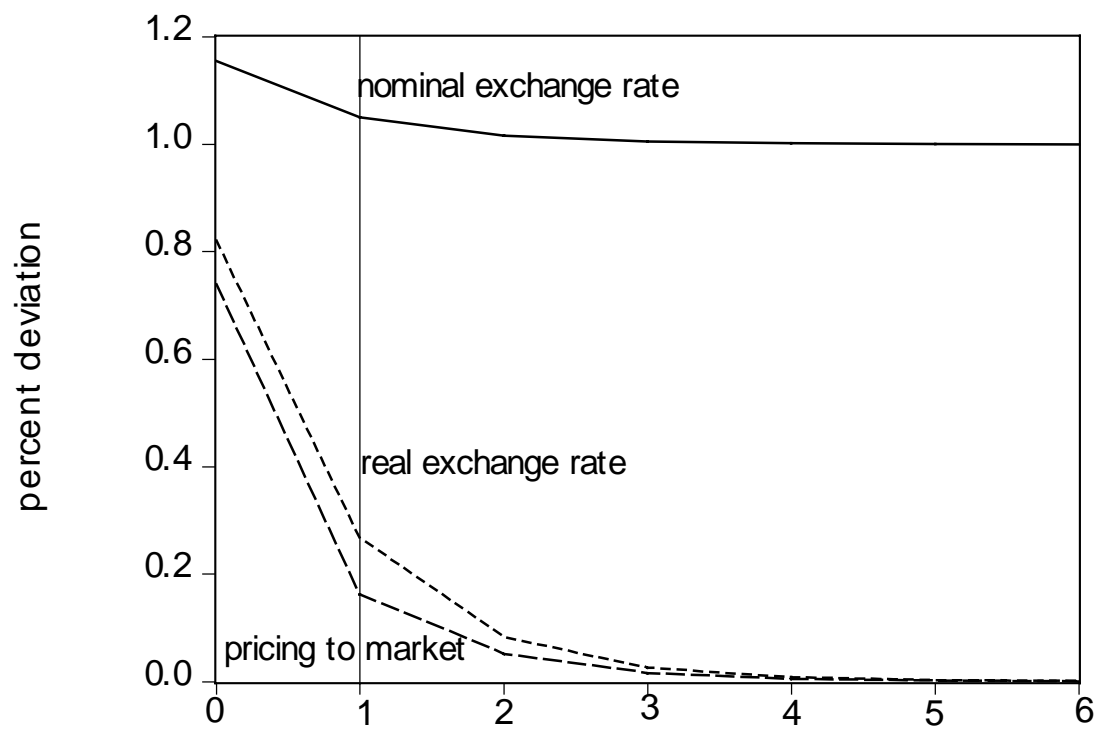

Years after monetary shock

Response to a permanent $1 \%$ increase in nominal money supply. One group resets price in initial period; both groups have resetprice one year after shock.

*Parameters: sigma $1=$ sigma2 $=5$, sigma $3=1$, theta $=0.85$, phi $=0.15$, gamma $=2$, beta $=0.96$. 


\section{Figure 5: Quantity Responses Alternative Parameterization*}

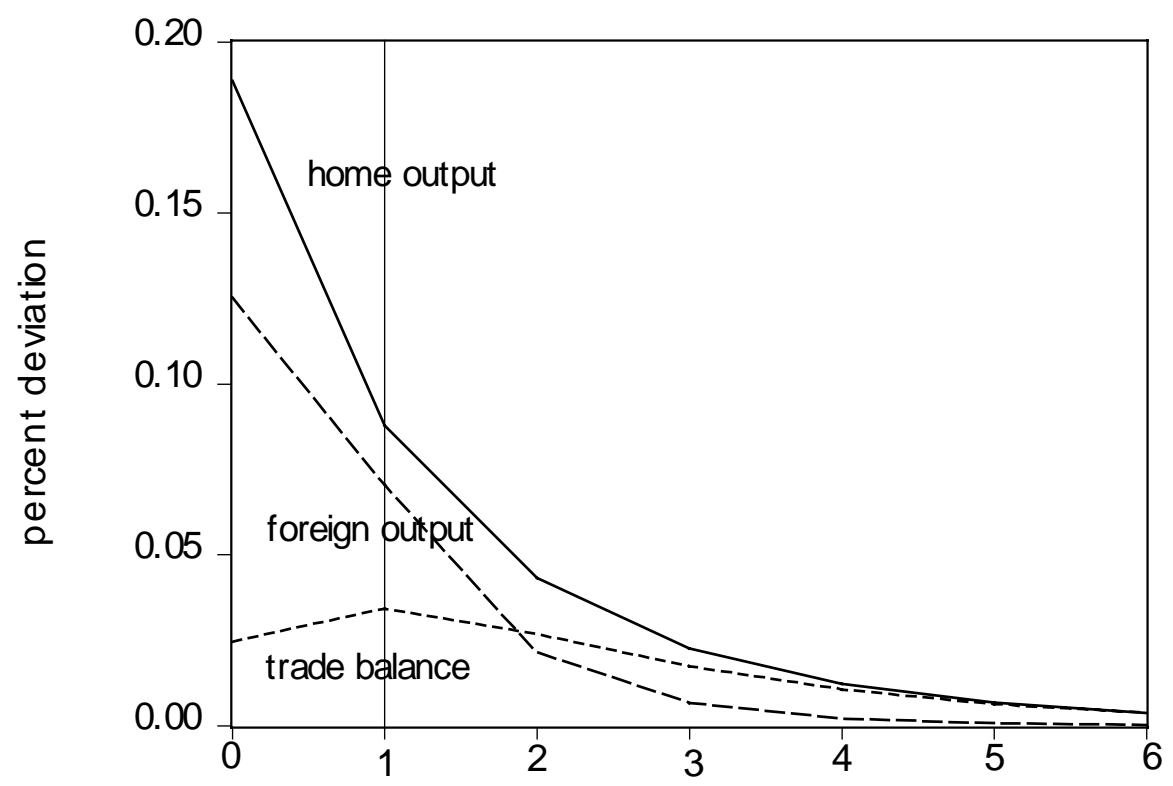

Years after monetary shock

Response to a permanent $1 \%$ increase in nominal money supply. One group resets price in initial period; both groups have resetprice one year after shock.

*Parameters: sigma $1=\operatorname{sigma} 2=5, \operatorname{sigma} 3=1$, theta $=0.85$, phi $=0.15$, gamma $=2$, beta $=0.96$. 